\title{
Navigating the 'grey areas': Australian medical travellers in China's stem cell bionetwork
}

\section{Introduction}

Stem cells, and their capacity to grow and regenerate new cells, have fuelled hope and hype around an imagined future of treatments and cures for a myriad of as-yet untreatable conditions (Brown, Kraft and Martin, 2006; Petersen and Krisjansen, 2015). Since major advances in the use of hematopoietic stem cells in the 1960s led to their now-standard application in bone marrow transplantations, hopes have remained high, with new breakthroughs at the level of basic science in the 1990s and early 2000s renewing excitement about potential treatments and cures (Maienschein, 2011). Nonetheless, this large and promising field of research still has not resulted in major translational breakthroughs since the initial discovery of the use of stem cells to treat blood-based disorders. Over the last two decades, however, clinics around the world have embarked on the controversial practice of selling various 'stem cell' treatments in advance of evidence that meets international scientific standards. For patients wanting the opportunity to try these treatments, the last 15 years has seen the rise of so-called 'stem cell tourism'.

The phenomenon has sparked fierce debate in the scientific community regarding ethical practices in stem cell research and clinical translation (Lau et al, 2008; Levine and Wolf, 2012; Sipp 2009, 2013), often demarcating between 'legitimate' and 'illegitimate' clinical practices (Petersen et al, 2015; Sleeboom-Faulkner, 2010). Treatments on offer target conditions for which no evidence-based

This is the author manuscript accepted for publication and has undergone full peer review but has not been through the copyediting, typesetting, pagination and proofreading process, which may lead to differences between this version and the Version of Record. Please cite this article as doi: 10.1111/apv.12162

This article is protected by copyright. All rights reserved. 
treatments have been established by Western scientific standards, such as spinal cord injury, autism, and certain neurodegenerative diseases such as amyotrophic lateral sclerosis (ALS). Criticism of the treatments focus on patients' safety, the potential for financial exploitation, as well as concerns that adverse outcomes could lead to a loss of public faith in promising stem cell treatments being developed under the standards of research and medical practice set by international peak institutions, such as the International Society for Stem Cell Research (ISSCR) (Regenberg et al, 2009; Munsie and Hyun, 2014; Murdoch and Scott, 2010; ISSCR, 2016; National Stem Cell Foundation of Australia, 2015).

The global market for treatments constitutes a constantly evolving landscape as national regulatory environments attempt to keep up with scientific advancements and social attitudes (Salter et al, 2014). It has also been argued that the hegemonic nature of Western scientific standards place unreasonable demands on countries that do not meet them (Salter et al, 2015; Sui and SleeboomFaulkner, 2015). As one such country, China has come under criticism in the science media (Cyranoski, 2012), attracting the Otherising moniker of the 'Wild East' (Chen, 2009; Song, 2011). Previous studies of stem cell tourism in Asia have sought to problematise dichotomised characterisations of unethical clinical practices allowed to proliferate in the East, versus careful and restrained research in the West by highlighting the globally integrated nature of such markets (Bharawaj, 2013; Chen and Gottweiss, 2013; Salter et al, 2015; Sleeboom-Faulkner and Patra, 2011; Song, 2011). They have also sought to develop a more nuanced picture of the people who travel to China and India through ethnographic studies in clinics (Song, 2010; Prasad, 2015; Sui and Sleeboom-Faulkner, 2015). 
As other papers in this Special Issue have demonstrated, much of the medical travel that takes place in Asia is intra-regional, and China is no exception (see, for example, Holliday et al., this issue). However, while China has not traditionally taken a large share of the global West to East flows of medical travellers - Thailand, Singapore and India being the major hubs — it has risen to prominence as a destination for those seeking highly experimental stem cell treatments (Rosemann, 2013). In questioning whether regulatory frameworks for stem cell research and clinical translation advocated for in wealthy countries are appropriate in the Chinese context, Sui and Sleeboom-Faulkner (2015) highlight the challenges involved when there is strong patient demand from both local Chinese and foreign patients. This article responds to the call for greater attention to the culturally-situated dynamics driving the phenomenon of stem cell tourism through a case study that draws together Australian patient subjectivities in Chinese stem cell clinics. It takes as its empirical focus the flow of Australian patients to China, but also draws in the voices of representatives of stem cell clinics in China. By situating Australian patients'subjectivities in the market for stem cell treatments in China, this article aims to highlight a tension between recent attempts within China to 'clean up' the socalled 'rogue' stem cell treatments in the context of geographically mobile patients and providers, and the socio-cultural factors that have sustained patient demands in Western, neoliberal countries where patients are exhorted to be proactive managers of their own health.

I begin by sketching out China's 'bionetwork' (Patra and Sleeboom-Faulkner, 2009) and describe some of the shifts in the landscape for treatments in China that have resulted in a patchwork of 'grey areas' between approved clinical practices and unauthorised experimentation (Sleeboom-Faulkner, 
2016). I then discuss the culturally-situated decision-making process for Australian patients contemplating a stem cell treatment in China, focussing on the moral imperative to act in the face of illness or injury. Two themes of Australians' experiences of navigating these grey areas as they embark on their journey in pursuit of stem cell treatments are explored: how patient morality becomes institutionalised in the market as evidenced in the accounts of the treatment providers, and how patients have responded to regulatory changes together with treatment providers, by both groups 'riding the wave' of regional shifts. I conclude with a discussion of the challenges this study raises for those with an interest in greater regulation of the flow of people travelling for stem cell treatments.

\section{Methods}

This article draws on a specific set of interviews within a broader Australian Research Councilfunded study into the socio-cultural and political underpinnings of so-called 'stem cell tourism' in Australia (Petersen et al, 2017). One hundred semi-structured qualitative interviews were conducted with a range of actors that broadly constituted the phenomenon of stem cell 'tourism' in Australia, China and Germany from 2012-2015 (Petersen et al, 2017). These included patients and their carers, clinicians and clinic representatives who offered stem cell treatments, scientists, regulators, representatives of patient organisations, and clinicians not involved in the provision of stem cell treatments (ibid, p.19). The focus of this article is the interview data that captures the flow of people and ideas between Australia and China. Six interviews took place with seven Australian patients and/or carers in January and February 2014, focusing specifically on their engagement with China as a destination for stem cell treatments. Four of these interviewees had travelled to China for treatment 
or to accompany their child or partner undergoing treatment; two had investigated the possibility of treatments in China but decided against stem cell treatments altogether; and one had considered treatment in China, but decided to take her child to Panama instead. These interviewees were recruited for a secondary interview about their engagement with China after they had volunteered to participate in the main study.

Interviews were also conducted in China with four representatives of three clinics offering unproven stem cell treatments in 2014 at their places of business. To develop a greater sense of the issues China has faced as the market has grown, two Chinese stem cell scientists with an interest in the regulation of stem cell research as well as one Chinese bioethicist were also interviewed. Bringing together these sets of data highlights both the local factors in Australia, as well as the influences of treatment providers in China, that see Australians making the choice to venture into the 'grey areas' of the landscape of commercially available stem cell treatments in China.

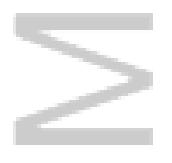

\section{The 'grey areas' of China's stem cell bionetwork}

Many countries have looked to their health and biotechnology sectors as a means of stimulating economic growth (Ong and Chen, 2010). China has specifically designated stem cell research as central to the project of nation-building (Zhang, 2014: 156). In 1986, under Deng Xiaoping's leadership, the 'National High-tech R\&D Program' was established with the aim of boosting 'China's overall high-tech development, R\&D capacity, socio-economic development, and national security' (Ministry of Science and Technology, 2006). In China's 10 ${ }^{\text {th }}$ Five-Year Plan (2001-2005), stem cell research was identified as a national priority as it was expected that 'through efforts made 
in the 5 years, the program will greatly enhance China's high-tech innovation capacity in selected fields and improve the international competitiveness of major industries' (Ministry of Science and Technology, 2006). 'Stem Cell and Tissue Engineering' has continued to be a 'Key Project' through the $11^{\text {th }}$ and $12^{\text {th }}$ Five-Year Plans (2006-2010 and 2011-2015), and China has somewhat successfully used its 'leap-frog' strategy to rapidly become a global presence in stem cell research (Ministry of Science and Technology, 2006; McMahon et al, 2010a, 2010b; Qin and Daverman, 2011). With significant state and private investment devoted to developing infrastructure that facilitates stem cell research and treatments, a commercial market for unproven stem cell treatments emerged alongside state-funded research activities, at times drawing on a combination of state and private funding, although also funded by the high fees that patients pay to undergo treatments.

Analysis of the commercial market for stem cell treatments in China is complicated by the variety of forms the treatment centres take, and the dynamic and changing nature of the market as it has grown and responded to peer and government regulatory forces. There are three main spaces in which commercial treatments have been available: state and military hospitals; private clinics and international hospitals; and biotechnology companies treating patients in rented hospital wards. Funding relationships are often opaque (Sipp, 2009; Zhang, 2014), and decreased public funding of the health care system over the last four decades has led to entrepreneurial practices being endemic in the system (Blumenthal and Hsiao, 2015). The opportunity to work in a relatively unregulated space has attracted foreign doctors and entrepreneurs who are interested in rapidly advancing clinical investigation of promising treatments, as well as lured back Chinese doctors and scientists from overseas positions. 
For most of the 2000s, the clinical application of stem cells went unregulated. In 2009, amid increasing international scrutiny and criticism of stem cell tourism to China, China's Ministry of Health (MoH) and China Food and Drug Administration (CFDA) released national guidelines requiring clinics to seek $\mathrm{MoH}$ approval for 'risky, ethically complex or unverified' treatments (Sipp, 2009). In 2012, after the 2009 regulations had little impact, the MoH and CFDA issued a ban on stem cell treatments, which included commercial unproven treatments and registered clinical trials approved by the CFDA that charged participants. Registered trials were instructed to 'follow the letter of authorities' instructions, with changes to the trials and profit-seeking banned' (Tam, 2012). The ban was expected to last for 6 months while new regulations were written to curb the availability of commercial stem cell treatments, while still supporting the research and development of evidencebased stem cell treatments under approved circumstances. In March 2013, three new regulations were announced that distinguished between clinical trials and stem cell treatments, with a ban on charging fees during the clinical trial phase (Zhang, 2014: 173), effectively extending the 2012 ban. While some public and military hospitals that had previously offered commercial stem cell treatments either suspended or ceased this practice, private clinics and biotechnology companyaffiliated clinics continued to take patients. After a longer than expected delay in drafting the new regulations, they were jointly introduced in August 2015 by the National Health and Family Planning Commission (formerly the MoH) and the CFDA (Rosemann and Sleeboom-Faulkner, 2016).

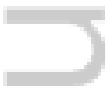

Despite attempts to improve its reputation for ethical oversight of research activities, China has struggled to make the leap from a producer of a high volume of research outputs to an influential 
member of the international stem cell research community (Zhang, 2014: 156-9). As Sui and Sleeboom-Faulkner (2015: 398) have argued, China is one of the many countries that has faced difficulties in adhering to the guidelines proposed by the ISSCR, highlighting that compliance requires investment in national scientific and health infrastructure that supports 'closely regulated, supervised, and highly skilled modes of doing research'. The increasingly strict regulations, even in 2014, had some impact in encouraging clinics, particularly those connected to state-funded research to suspend clinical application of stem cells. As the scientist interviewees in this study described the situation, this has been primarily through self-regulation. According to them, in smaller cities, further away from Beijing, it would be possible to find facilities and obtain a license from local authorities to continue experimentation. Nonetheless, in 2014, many of the state and military hospitals that had previously courted international stem cell travellers through their internet presence had removed their websites.

The private clinics that participated in this study continued taking fee-paying patients despite the ban, counting on regulatory uncertainty and a lack of enforcement. One representative contended that since the initial six-month ban on the clinical application of treatments had expired with nothing in its place, there were in effect no regulations. The other representative, who had moved to China from a Western country to pursue clinical experimentation, saw the regulatory changes as a measure to improve the reputation of state-funded research centres, with private clinics courting foreign patients being too marginal to attract sanction. As he saw it, 
The numbers are in the Chinese. I mean they're sitting in the middle of a billion and a half people, I mean, a few hundred or a few thousand medical tourists or whatever you want to call them, coming in a day is pretty marginal. Erm, maybe they don't wanna piss everybody else in the world off, maybe they just let sleeping dogs lie, um, I don't know. But it's like everything else in China, there's kind of, erm... shades of grey.

These 'shades of grey' have led to a diverse patchwork of clinical and regulatory environments to which foreign patients have been travelling for over a decade. As the clinic representative suggests, it is impossible to extricate the local situation in China from the global bionetwork that has contributed to China's market for stem cell treatments. Patra and Sleeboom-Faulkner have proposed the term 'bionetwork' to capture the broader entanglement of people, ideas and institutions in relation to life science industries (Patra and Sleeboom-Faulkner, 2009; Sleeboom-Faulkner and Patra, 2011; Sleeboom-Faulkner, 2016). One element of this bionetwork that this article will now explore is that of the people who travel for treatments.

\section{Australians in China's stem cell bionetwork}

Many who are suddenly faced with an unexpected illness or disability come up against the limits of what the health care system can provide, or the limits of scientific knowledge. It might be assumed that those who travel for unproven treatments are gullible or desperate, but as this study and other research with travellers suggests (Chen and Gottweiss, 2013; Petersen et al, 2014; Petersen et al, 2017; Prasad, 2015; Song, 2010), the picture is far more complex. In the context of increasingly borderless healthcare markets, national borders no longer limit access to treatments for those with the 
means to travel. For patients and their loved ones, being confronted with a dire prognosis is just the beginning of a long journey of researching and discussing treatment options with doctors, friends, family, disease-specific patient organisations, as well as searching the internet. During this period, as our larger study revealed, patients face a number of critical junctures in their decision-making process, with some choosing to travel, and others taking alternative paths of action (Petersen et al, 2017, p.45-9). In the case of the China-specific interviews on which this article focuses, two of the interviewees chose alternative paths of action to travelling- undertaking skills training to adjust to life as a carer, searching out alternative experimental drug protocols, or monitoring research outputs and clinical trials to find something more promising than the treatments being proposed by clinics online.

Until the recent growth of a local stem cell treatment market in Australia (Munsie and Pera, 2014), the story of stem cell tourism has been one of outbound travellers. In regard to the phenomenon of stem cell tourism, the assumption has been that offering more or 'better' information to those contemplating such treatments may dissuade them from travelling (Petersen et al, 2017). This approach implies that patients 'weigh up' information in a rational manner, and that the information they seek is reliable and trustworthy (Petersen and Seear, 2011, p.330; Seear et al., 2010, p.15). While patients are thrown into a situation of having to apply supposedly objective processes of rational decision-making by 'weighing up' evidence and choosing the 'best' option, such decisionmaking in these circumstances is coloured by questions of urgency, which sources of information to trust, and what course of action, if any, is the 'right' thing to do. 


\section{Patients and the moral imperative to do something}

Previous studies have highlighted the role of hope and expectations in decisions to travel (Petersen et al., 2017; Petersen and Seear. 2011; Seear et al., 2010; Song 2010). However, the moral dimension of this decision-making process has been underexplored in the literature on stem cell tourism. In Western neoliberal societies, such as Australia, as one of many manifestations of the neoliberal call to self-responsibility (Rose and Miller, 1992), citizens are increasingly encouraged to take control of their own health care decision-making, such as becoming 'informed' and active consumers of healthcare, and proactive caretakers of their own health (Rose and Novas, 2005). Rose (2007: 26) has noted the moral dimension of this phenomenon, observing that while the expectation is for individuals to shape their life course through 'acts of choice', “"biology” will not easily be accepted as fate or responded to with impotence'. Anxiety about one's own health or that of a loved one also 'generates a moral economy in which ignorance, resignation, and hopelessness in the face of the future is deprecated' (Rose, 2007: 26-7). For the patients and carers in this study, this was evidenced in their stories of actively searching for the 'right' course of action in the face of illness.

A common starting point for patients in recounting their decisions to travel was the moment of diagnosis. For one interviewee in particular, a carer to her husband who was diagnosed with Lewy Body Dementia - a form of dementia characterised by Parkinsonian features of cognitive and physical decline, that moment was particularly blunt:

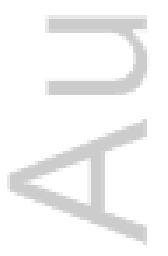


The information from the neurologist was less than helpful. Erm, when I said to him "so what can we do?" His response for that was "nothing." No elaboration on that word, just "nothing".

For people like her, this is the beginning of a long journey of researching and discussing treatment options. Even for doctors who do commit to working with patients to help navigate the uncertain journeys into unconventional treatment options, there are limits to what the health care system can provide. As one patient interviewee explained, his doctor remained supportive of his quest to continue pursuing experimental treatments after his diagnosis of primary progressive multiple sclerosis. He began to search clinical trial databases and discuss any promising protocols with his doctor. As he described, when he found an experimental protocol for the therapeutic use of antibiotics for multiple sclerosis, he took it back to his doctor.

He came up with this regime of antibiotics, and you're on it 12 months, three different antibiotics, and yeah, I've been going to my GP, and he said, 'yeah, if you want to give it a go, you pay the money.' So he gives me the prescription. The chemist, one of them wanted $\$ 83$ for ten tablets and you have to take them every second day for 12 months. Ended up getting them in India for, well, that saved me $\$ 1200$.

For this interviewee, stem cell treatment was just one among many options he considered, framed by the urgency of having a progressive condition. He expressed a strong opinion that over- 
bureaucratisation of regulation, as well as the commercial aspect of the biotechnology sector was preventing his access to experimental treatments within his limited time frame.

[With my condition], you're not supposed to get better.... You can plateau, but you're supposed to just keep going downhill... You have [this] ridiculous, well, criminal bloody control system on all this [experimental] stuff.... I mean, [regulation] was originally designed to, you know, protect people from snake oil salesmen and shit, but now it's progressed to the stage where it's completely controlled by drug companies and it's manipulated to just benefit their profits.

Despite his disdain for drug companies, he was still interested in stem cell treatments, albeit finding the cost prohibitive. His story is also representative of the feeling expressed by many people who travel for stem cell treatments; that is, they are being 'denied' access by bureaucratic hurdles, or that funding decisions are being made in a way that deprioritises research and clinical translation for their condition. There is also the notion that compared with other countries, where the regulatory environment differs and allows access to highly experimental treatments, Australians are missing out on treatments due to overly-cautious regulation.

The sense of abandonment, and feeling of anger or frustration at a state that makes funding and governance choices that seem to limit access to treatments can also serve to decrease the legitimacy of the state, displacing power and authority to other, non-state actors. In this context, patients have come to see peers as trusted sources of advice (Patra and Sleeboom-Faulkner, 2011; Petersen et al, 
2014, 2017). This serves to destabilize the notion of who the 'expert' is, and whose advice is authoritative. For patients or carers who are frustrated by a perceived lack of interest from medical professionals and who have been engaging in their own lay accumulation of knowledge about their condition or that of their child or loved one, the much-criticised anecdotal stories presented by stem cell treatment providers or other past patients can be compelling evidence to try a clinically unproven treatment. Patients or carers becoming interested in stem cell treatments at times turn to their doctors for advice. However, responses can be equivocal or dismissive, leaving patients to turn to alternative sources for advice when 'doing nothing' is not an option. These patients and carers exemplify Rose's argument that as citizens are increasingly exhorted to actively shape their own life course, the prospect of illness or disability is leading to a moral economy fuelled by hope for the future that sees people unwilling to accept biology as fate (Rose, 2007).

For those who choose to travel, trust was built by the providers of the stem cell treatments through a therapeutic relationship that promised to give them a meaningful course of action, with the hope they may have a chance of halting progression of their condition, or even improvement or a cure. Those who chose not to travel showed a lack of trust in stem cell treatment providers, but also described other meaningful courses of action. In the case of the participant who was able to pursue experimental drug therapy with the assistance of his general practitioner, he had developed a therapeutic relationship with a sympathetic practitioner in his own community. This suggests that the difference between those who travel and those who do not is not a divergence of moral frameworks, but rather where they place their trust and with whom they can develop a therapeutic relationship. 


\section{Providers in the grey areas}

The personal morality of the providers of commercial stem cell treatments has been the subject of fierce debate. Some characterise them as 'quacks' or 'charlatans', others as the 'helping doctor', 'meeting the needs of patients', and others still as 'pioneers'. However, as DelVecchio Good (2001) has written in relation to oncology and high technology medicine, patients, clinicians, scientists and venture capitalists are all susceptible to the 'biotechnical embrace' of promising new technologies. Like the people who travel, treatment providers also expressed frustration at the slow rate of research and clinical translation inherent in the hegemonic Western scientific model. One provider welcomed a perceived lack of regulation in China, which allowed him to work in the 'grey areas' where he could attempt to rapidly advance stem cell treatments. As a Western doctor running a clinic in a private hospital, he explained that he had specifically gone to China because of the 'grey areas'.

[I]f you wait for the kind of trials that have become de rigour in the [West], nobody's going to benefit from them in our lifetime, I mean it's impossible. It's become like a lot of things in that system, so overly bureaucratic and defensive, it is stuck, it becomes a paradox: you can't help people because you're too timid to risk hurting them.

He argued that the most rapid breakthroughs have always occurred outside standard medical practices, and while he acknowledged that China was attempting to regulate, he did not seem concerned that he would be a target. As previous studies have found, many patients are also looking for less regulated areas in which they can participate in speeding up the progress of research into their condition (Seear et al, 2010; Song, 2010). According to one interviewed Australian patient who 
considered travelling to China (but decided against it after unconvincing communication from the one clinic he contacted regarding the evidence to support their claims), the lack of regulation meant he could potentially gain access to promising treatments, which he also saw as being held back by the lengthy clinical trial process.

I've got primary progressive [multiple sclerosis]. There's currently no approved treatments because no one had done the bloody tests, and why not? Why not give it a go?

However, given the lack of transparency around the collection of data, the question remains as to whether these treatments will lead to the development of evidence-based treatments, or whether they are unnecessarily exploiting willing patients. Some providers use the language of clinical trials, although treatments do not adhere to international standards. While they make a case for the 'bedside to bench' model of clinical translation, it is highly speculative, and may not deliver on much of the promise inherent in their claims (Petersen and Krisjansen, 2015). One clinic representative noted the limitations on collecting long-term data within the medical travel framework, where patients disappear after returning home. Some patients reported their clinic requesting self-assessed questionnaire-based data in the months following, this relies on continued patient engagement-the strong patient demand and the rhetoric of the 'right to try' is a common justification in the interviews with stem cell treatment providers.

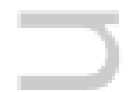

Yet, this also obscures the efforts that providers go to in actively cultivating that trust, as well as actively working to direct patients looking for treatment to their clinic. Providers in this study 
described practices such as shaping the online search environment for patients through search engine optimisation campaigns, use of past patients for personal recommendations, and the use of nonmedical clinic concierges to help manage the patient experience. One also described the use of payments to medical tourism facilitators or representatives of embassies in certain countries to direct patients to his clinic. The way treatment providers frame their treatments legitimates the desire for action, which enhances the sense of trust in people who are looking for an active and engaged medical practitioner. The two patients in this study who chose not to travel after contacting clinics in China described unsatisfactory interactions with clinic representatives that failed to establish legitimacy for their treatments, and raised suspicion about the clinic's motivations.

Riding the wave of regional shifts

Beike Biotechnology (heneceforth 'Beike') has been a much-studied example of the controversial adoption of 'bedside to bench' models of clinical translation (Chen and Gottweiss, 2013; SleeboomFaulkner, 2016), whereby treatments are sold to patients for a wide variety of conditions, and those that show promise are then investigated further in the laboratory. However, as Sleeboom-Faulkner (2016) argues, Beike has not been seen as an unethical enterprise within China, despite not adhering to Western scientific standards. Founded in 2005, it has since been exploring options for treatment centres outside China, further expanding China's stem cell bionetwork. By 2012, in response to the initial ban on commercial treatments and already having partnerships with clinics outside China, they closed their treatment centres in China but continued facilitating treatment elsewhere. Private hospitals in Thailand also operate in spaces of regulatory uncertainty, where providers may be able to exploit regulatory loopholes (Sipp, 2009; Whittaker and Chee, 2015). Nonetheless, for Beike, this 
allowed them to maintain potential access to the Chinese market in the future by being compliant with the ban in China and maintaining a good relationship with the government, with a view to reopening treatment centres in China if the regulatory environment becomes favourable to their practices.

Patients in this network were also flexible and willing to adapt in the face of regulatory shifts, particularly those who have developed a relationship with providers and see them as trusted medical practitioners. For those who want to pursue stem cell treatments, regulatory changes may only be an inconvenience rather than a deterrent. For example, one Australian interviewee, who cared for her young son with cerebral palsy, had been to Germany, China and Thailand-all in response to regional shifts in regulation. While she had initially chosen Germany for the implied technological advancement, changes to the regulation of stem cell research and clinical translation, as well as the closure of the clinic they had travelled to following the death of a child undergoing treatment there, compelled her to look elsewhere. While China was not an obvious choice for her due to preconceived notions about safety and quality, an opportunity to visit for business changed her impression of the overall modernity of the country and she felt she would be able to trust a clinic there. However, after taking her son for multiple visits to a Beike-affiliated clinic in China, and perceiving a positive outcome, the regulatory shift in China has led her to continue to plan future treatments at a Beike-affiliated clinic in Thailand, which seemed to be a permanent relocation at the time of the interview. She explained: 
Originally they must have thought that things in China will change quickly and they just found themselves a partner in Bangkok whom they just had [a] certain contract with and were paying a certain amount and that facility was taking their patients. But I think now they realise because it's dragged on for a little bit too long, they were in discussions on doing a partnership with [a] Thai company. And at the time when we were leaving they were looking for a new hospital and they were signing a 30-year lease and were going to rent [a] much bigger building and obviously do a full fit-out and they would be able to take more patients in.

The way Beike's geographical shift has been presented to patients is unclear. This interviewee appeared to have a grasp of the regulatory challenges Beike had faced, and was unconcerned about any questions it may raise about safety or efficacy of their treatments. However, another Australian interviewee, a mother of a child who had been diagnosed with autism, believed that she was being redirected to Thailand because it was a centre that was set up to better cater for children undergoing treatment. One of the consequences of the delay in drafting the new 2015 regulations has been to push geographically flexible companies into other parts of Asia, taking patients with them. The two interviewees who had been to both China and Thailand expressed a preference for the affective dimension of care they experienced in the Thai clinic. To what extent this will have long-term regional implications on the flow of people travelling for stem cell treatments is unclear, although it continues the pattern of new markets emerging in less regulated spaces as established ones come under tighter regulatory control. 


\section{Shifting landscapes: expanding the grey areas?}

China is increasingly attempting to shape the market for stem cell treatments through top-down regulatory measures as it seeks to position itself as a global destination for stem cell research and clinical translation. However, as Zhang (2014: 157-8) notes, for China to be able to capitalise on their investment in stem cell research, it needs to 'acquire a voice' conforming to Western scientific 'grammar'. In the context of the rapidly changing regulatory environment, struggling to keep up with advancements in stem cell science, Sui and Sleeboom-Faulkner (2015) provide a detailed history of the measures the government has taken to reshape and diminish the spaces in which clinics have been selling treatments considered unethical by Western standards. New laws, enacted in August 2015, have aimed for better gatekeeping of who can work with stem cells (by restricting which hospitals have permission to conduct research, trials or offer stem cell treatments), enhancing product safety by creating standard operating procedures, and reinforcement of informed consent protocols (Rosemann and Sleeboom-Faulkner, 2016). The extent to which treatment providers that do not receive approval will be able to continue to operate remains to be seen.

In 2014, the Chinese scientists interviewed in this project explained that the intention for the new legislation was to establish China as a centre for clinical trials, which may be able to test some of the claims of unproven treatment providers, noting that providers only share data that supports their treatment protocols. This selective use of data was confirmed by one stem cell treatment provider in this study who explained that if patients do not have a good outcome, their story is not recorded or presented on their website. Some in the Chinese scientific community argue that regulation that can provide them with an opportunity to speed up investigations of some of the claims to efficacy made 
by providers of unproven treatments will act as a means of marginalising those not complying with standard practice. Even if the regulations fail to curtail the availability of unproven treatments, a greater understanding of the efficacy of treatments (or lack thereof) being offered may put pressure on providers of unproven treatments to move towards more evidence-based treatments. As one of the scientist interviewees explained,

We are going to start the multi-centre clinical trial, and then make the conclusion [whether these treatments are] good for neurological diseases or spinal cord injury, or different. So we are going to get a conclusion on it. For example, the neurological programs, if the clinical trial shows it is positive, we are going to publish the procedure so that [everyone] can follow the procedure... If we get a negative result, we will publish that also, saying this treatment for this certain disease is not working, so the patient doesn't need to spend their money.

While this may allow for more promising treatments to be tested more quickly, trialling treatments that lack even the most basic pre-clinical data to warrant investigation would still be problematic, and still not solve the tension between Western scientific frameworks and those who want to find ways to speed up clinical investigation and experimentation. Clinics argue that their treatments do have sufficient evidence to warrant their use, so some patients may not want to participate in a clinical trial if the treatment is anecdotally 'proven'.

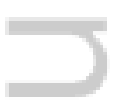

Since this research was carried out, further global shifts have already begun to challenge China's position in the global market. Recent developments in the United States, particularly the introduction 
of the Right to Try bill that allows for compassionate access to highly experimental treatments, have meant that the USA has become the country with the highest number of clinics offering clinically unproven stem cell treatments (Berger et al, 2016). Australia also now has a burgeoning stem cell treatment market, which is capitalising on an exemption of autologous stromal vascular fraction cells (derived from fat cells) from the legislation that regulates therapeutic goods (Munsie and Hyun, 2014; Lysaght et al, 2015), with anecdotal reports of inbound patients from Asia. While China is still considered a top destination, as the global landscape rapidly shifts, the extent to which China will remain a key destination country is uncertain. Primary analysis of the 2015 laws suggests that while they may have some impact on strengthening the legitimacy of state-funded research centres, the extent to which they will have an impact on the more marginal clinics to which international patients are travelling balances on a number of factors-including how regional governments interpret and implement them, the response from the well-established local and international networks that sustain them, and uncertainty about how any enforcement action might occur in practice (Rosemann and Sleebooom-Faulkner, 2016). For the patients travelling from Australia, the burgeoning market in Australia may moderate the need to travel at all in the future.

\section{Conclusion}

As a form of medical travel, stem cell tourism has proven to be highly controversial and ethically fraught. For the Australians in this study, coming up against the limits of what conventional medicine can offer them jars against the social expectation that they will be active, engaged and selfresponsible managers of their health or that of a loved one they care for. Like clinics the world over, Chinese stem cell treatment clinics have been able to capitalise on the demand for action in the face 
of serious illness, allowing treatment centres to proliferate in a variety of institutions. Commentary that appeals to the dichotomised East/West characterisation of the market in China obscures the globally integrated nature of China's stem cell bionetwork. Foreign doctors and entrepreneurs have also moved in to take advantage of the opportunities afforded by working in the grey areas. As Sleeboom-Faulkner (2016) argues, there is a need to understand how local factors have shaped the development of the market in China, and why practices that may have been frowned upon internationally have been considered ethically acceptable locally. This article has argued for an expansion of this understanding to include the interplay of local factors in the countries that host markets for stem cell treatments, as well as the local factors that shape the decision-making processes of the people who travel to those countries.

In choosing to travel to China to access unproven treatments, patients are entering complex grey areas, where Chinese and non-Chinese providers and other entrepreneurs are also drawn in by the biotechnical embrace of the regenerative potential of stem cells, and where the potential for exploitation exists as there is little regulation to protect patients. For patients who want to participate in government-approved experimental research activities, the new laws in China may help them navigate the shades of grey that have constituted the stem cell treatment landscape there over the last decade. As this article has discussed, however, there is also a need to understand the culturallysituated decision-making processes that patients experience in deciding whether to travel or not. Appeals from regulators to trust in scientific evidence fail to take into account the social context in which people are making their choices whether to travel or not. For patients who feel the moral imperative to do something, being told that there is 'nothing' to be done is not easily accepted. 
Finding a representative of a clinic who speaks to that need, can be a powerful motivator for a patient or carer to make that difficult and fraught decision to travel.

Regardless of what may motivate them, treatment providers have been able to capitalise on this moral imperative to do something by cultivating trust and, in some cases, developing a therapeutic relationship with patients. For patients who see value in their visits, they are also willing to ride the waves of regional and international regulatory shifts in order to continue pursuing treatment and these ongoing therapeutic relationships. In recent years, these regional shifts in regulation have also seen the rise of a market for stem cell treatments in Australia, which, for the Australians in this study at least, may challenge whether they see the need to travel as all. Nonetheless, this article highlights the challenges for top-down regulatory mechanisms contained by national borders. For those with an interest in deterring patients from entering into such patchworks of grey areas (whether in China or elsewhere), there is a need for a greater understanding of the motivations for those who travel. Meeting the needs of patients and/or carers in other ways may require an interrogation of how local health care communities can be strengthened to broaden the notion of meaningful action after a diagnosis, so that the answer to the question of what there is to be 'done' is not 'nothing'.

\section{References}

Berger, I., Ahmad, A., Bansal, A., Kapoor, T., Sipp, D. and Rasko, J. E. (2016). Global distribution of businesses marketing stem cell-based interventions. Cell Stem Cell. 19: 158-162. Bharawaj, A. (2013) Ethic of Consensibility, subaltern ethicality: the clinical application of embryonic stem cells in India. BioSocieties 8: 25-40. 
Blumenthal, D. and Hsiao, W. (2015) Lessons from the East: China's rapidly evolving health care system, The New England Journal of Medicine 372: 1281-1285.

Brown, N., Kraft, A. and Martin, P. (2006) The promissory past of blood stem cells. BioSocieties. 1(3): 329-348.

Chen, H. (2009) Stem cell governance in China: From bench to bedside, New Genetics and Society 28(3): 267-282.

Chen, H. and Gottweis, H. (2013) Stem cell treatments in China: Rethinking the patient role in the global bio-economy. Bioethics 27(4): 194-207.

Cyranoski, D. (2012) China's stem cell rules go unheeded, Nature 484.

DelVecchio Good, M. (2001) The biotechnical embrace. Culture, Medicine \& Psychiatry 25(4): 395 410.

ISSCR. (2016) Guidelines for Stem Cell Research and Clinical Translation. International Society for Stem Cell Research., Retrieved 23 November, from website:

http://www.isscr.org/home/publications/2016-guidelines

Lau, D., Ogbogu, U., Taylor, B., Stafinski, T., Menon, D. and Caulfield, T. (2008) Stem cell clinics online: The direct-to-consumer portrayal of stem cell medicine. Cell Stem Cell. 3(6): 591-594.

Levine, A. and Wolf, L. (2012) The Roles and Responsibilities of Physicians in Patients' Decisions about Unproven Stem Cell Therapies, Journal of Law, Medicine \& Ethics Spring: 122-134.

Lindvall, O. and Hyun, I. (2009) Medical Innovation Versus Stem Cell Tourism, Science 324: 16641665.

Lysaght, T., Kerridge, I., Sipp, D., Porter, G. and Capps, B. J. (2015) Ethical and Regulatory Challenges with Autologous Adult Stem Cells: A Comparative Review of International 
Regulations, ARI Working Paper, No. 22, National University of Singapore. Retrieved 31 July 2015, from website: http://www.ari.nus.edu.sg/publication/working-papers.html.

Maienschein, J. 2011. Regenerative medicine's historical roots in regeneration, transplantation, and translation. Developmental Biology 358(2): 278-284.

McMahon, D., Thorsteindóttir, H., Singer, P. and Daar, A. (2010a) China's Recipe for Stem Cell Success: The Yin and Yang of Regenerative Medical Research and Therapy, Science Progress. Retrieved 31 July 2015, from website: http://scienceprogress.org/2010/02/china-stem-cell/ McMahon, D., Thorsteindóttir, H., Singer, P. and Daar, A. (2010b) Cultivating Regenerative Medicine Innovation in China, Regenerative Medicine 5(1): 35-44.

Munsie, M. and Pera, M. (2014) Regulatory loophole enables unproven autologous cell therapies to thrive in Australia. Stem Cells and Development 23(S1): 34-38.

Munsie, M. and Hyun, I. (2014) A Question of Ethics: Selling Autologous Stem Cell Therapies Flaunts Professional Standards. Stem Cell Research 13(3): 647-653.

Murdoch, C. and Scott, C. (2010) Stem Cell Tourism and the Power of Hope. The American Journal of Bioethics 10(5): 16-23.

National Stem Cell Foundation of Australia (2015) The Australian Stem Cell Handbook. National Stem Cell Foundation of Australia and Stem Cells Australia. Retrieved 31 July 2015, from website: http://www.stemcellsaustralia.edu.au/AboutUs/Document-Library/PatientInformation.aspx

Ong, A. and Chen, N. eds. 2010 Asian Biotech: Ethics and Communities of Fate. Durham and London: Duke University Press.

This article is protected by copyright. All rights reserved. 
Patra, P. K. and Sleeboom-Faulkner, M. (2009) Bionetworking: Experimental stem cell therapy and patient recruitment in India. Anthropology \& Medicine 16(2): 147-163.

Patra, P. K. and Sleeboom-Faulkner, M. (2011) Recruiter-patients as ambiguous symbols of health: Bionetworking and stem cell therapy in India, New Genetics and Society 30(2): 155-166.

Petersen, A. and Krisjansen, I. (2015) Assembling "the bioeconomy": exploiting the power of the promissory life science, Journal of Sociology 51(1): 28-46.

Petersen, A., Munsie, M., Tanner, C., MacGregor C, and Brophy, J. (2017) Stem Cell Tourism and the Political Economy of Hope. Basingstoke: Palgrave Macmillan.

Petersen, A. and Seear, K. (2011) Technologies of hope: Techniques of the online advertising of stem cell treatments, New Genetics and Society 30(4): 329-346.

Petersen, A., Seear, K. and Munsie, M. (2014) 'Therapeutic journeys: The hopeful travails of stem cell tourists' Sociology of Health and Illness 36(5): 670-685.

Petersen, A., Tanner, C. and Munsie, M. (2015) Between hope and evidence: how community advisors demarcate the boundary between legitimate and illegitimate stem cell treatments, Health: An Interdisciplinary Journal for the Social Study of Health, Illness and Medicine 19(2): $188-206$.

Prasad, A. 2015. Ambivalent journeys of hope: Embryonic stem cell therapy in a clinic in India.

Health: An Interdisciplinary Journal for the Social Study of Health, Illness, and Medicine. 19(2), pp.137-153.

Rose, N. (2007) The politics of life itself. Theory, Culture \& Society. 18(6), pp.1-30.

Rose, N. and Miller, P. (2010) Political power beyond the State: problematics of government. British Journal of Sociology 61:271-303. 
Rose, N. and Novas, C. (2005) Biological Citizenship. In: Ong, A. and Collier, S.J. eds. Global Assemblages: Technology, Politics, and Ethics as Anthropological Problems. Massachusetts, Oxford and Victoria: Blackwell Publishing, pp.439-463.

Rosemann A. (2013) Medical innovation and national experimental pluralism: Insights from clinical stem cell research and applications in China. BioSocieties 8(1): 58-74.

Rosemann, A. and Sleeboom-Faulkner, M. (2016) New regulation for clinical stem cell research in China: expected impact and challenges for implementation. Regenerative Medicine 11(1): $5-9$.

Qin, S. and Daverman, R. (2011) China's 12th Five Year Plan for Medical Technology, ChinaBio. Retrieved 31 July 2015, from website: http://www.chinabiotoday.com/articles/20111202_3 Regenberg, A., Hutchinson, L., Schanker, B. and Mathews, D. (2009) Medicine on the Fringe: Stem Cell-Based Interventions in Advance of Medical Ethics, Stem Cells 27: 2312-2139.

Salter, B., Zhou, Y. and Datta, S. (2014) Health consumers and stem cell therapy innovation: markets, models and regulation. Regenerative Medicine 9(3): 353-66.

Salter, B., Zhou, Y. and Datta, S. (2015) Hegemony in the marketplace of biomedical innovation: Consumer demand and stem cell science. Social Science \& Medicine 131: 156-63.

Seear, K., Petersen, A., Munsie, M. and Skinner, R. (2010) Hopeful Journeys: Experiences of Stem Cell Treatments Offered Outside Australia, School of Political and Social Inquiry, Monash University. Retrieved 31 July 2015, from website:

http://www.industry.gov.au/industry/IndustrySectors/nanotechnology/Publications/Documents/H opeful_Journeys_Stem_Cell_Treatment.pdf 
Sipp, D. (2009) The Rocky Road to Regulation, Nature Reports Stem Cells. Retrieved 31 July 2015, from website: http://www.nature.com/stemcells/2009/0909/090923/full/stemcells.2009.125.html

Sipp, D. (2013). Direct-to-consumer stem cell marketing and regulatory responses. Stem Cells Translational Medicine 2(9): 638-640

Sleeboom-Faulkner, M. (2010) Boundary making and 'good' stem cell research (SCR) in mainland China: including bioethics, excluding debate, East Asian Science, Technology and Society 4(1): $31-51$.

Sleeboom-Faulkner, M. (2016) The large grey area between 'bona fide' and 'rogue' stem cell interventions-Ethical acceptability and the need to include local variability. Technological Forecasting \& Social Change 109: 76-86.

Sleeboom-Faulkner, M and Patra, P.K. (2011) Experimental stem cell therapy: biohierachies and bionetworking in Japan and India. Social Studies of Science 41(5): 696-707.

Song, P. (2010) Biotech pilgrims and the transnational quest for stem cell cures, Medical Anthropology 29(4): 384-402.

Song, P. (2011) The proliferation of stem cell therapies in post-Mao China: Problematising ethical regulation, New Genetics and Society 30(2): 141-153.

Sui, S. and Sleeboom-Faulkner, M. (2015) Governance of stem cell research and its clinical translation in China: An example of profit-oriented bionetworking. East Asian Science, Technology and Society 9: 397-412.

Tam, F. (2012) Halt to rogue stem-cell therapy, South China Morning Post. Hong Kong. Published online 11 January. Retrieved 31 July 2015, from website: http://www.scmp.com/article/989799/halt-rogue-stem-cell-therapy. 
Ministry of Science and Technology (2006) National High-tech R\&D Program (863 Program). Retrieved 31 July 2015, from website: http://www.most.gov.cn/eng/programmes1/200610/t20061009_36225.htm.

Tanner, C. and Munsie, M. (2014) Seeing the full picture: The hidden cost of the stem cell and regenerative medicine revolution, in A. Pébay (ed.), Regenerative Biology of the Eye. New York: Springer Science+Business Media: 291-304.

Whittaker, A. and Chee, H. L. (2016) Flexible bio-citizenship' and international medical travel: Transnational mobilities for care in Asia. International Sociology 31(3): 286-304.

Zhang, J. Y. (2014) Does China offer a new paradigm for doing science?, in D. Kerr (ed.) China's Many Dreams: Comparative Perspectives on China's Search for National Rejuvenation. London: Palgrave Macmillan: 156-179.

This article is protected by copyright. All rights reserved. 
Navigating the 'grey areas': Australian medical travellers in China's stem cell bionetwork

Dr Jane Brophy

Monash University, School of Social Sciences, 500 Wellington Road, Clayton, Vic,

Australia, 3800

Email:jane.brophy@monash.edu

Phone: +61418803805

Postal address: 37/355 Rathdowne Street, Carlton, Vic, Australia, 3053

This article is protected by copyright. All rights reserved. 


\section{University Library}

\section{- M M N E R VA A gateway to Melbourne's research publications}

Minerva Access is the Institutional Repository of The University of Melbourne

Author/s:

Brophy, J

Title:

Navigating the 'grey areas': Australian medical travellers in China's stem cell bionetwork

Date:

2017-08-01

Citation:

Brophy, J. (2017). Navigating the 'grey areas': Australian medical travellers in China's stem cell bionetwork. Asia Pacific Viewpoint, 58 (2), pp.216-227. https://doi.org/10.1111/ apv. 12162.

Persistent Link:

http://hdl.handle.net/11343/293271 